\title{
Study on knowledge management and open innovation
}

\section{Estudio sobre la gestión del conocimiento y la innovación abierta}

\author{
ARREDONDO-SAFA, Judith*†, PEREZ-ROMERO, Luis Alfonso and CASTRO-VALENCIA, Alberto \\ Merced
}

Universidad Autónoma de Guadalajara. Av. Patria 1201, Lomas del Valle, 45129 Zapopan, Jal.

ID $1^{\text {st }}$ Author: Judith, Arredondo-Safa / ORC ID: 0000-0001-9923-5915

ID $1^{\text {st }}$ Coauthor: Luis Alfonso, Perez-Romero / ORC ID: 0000-0002-0741-2820, Research ID:556633

ID $2^{\text {nd }}$ Coauthor: Alberto Merced, Castro-Valencia / ORC ID: 0000-0001-8160-9077, Researcher ID Thomson: D-34622018, arXiv Author ID: 2776339, PubMed Autor ID: D-3462-2018, CVU CONACYT ID: 222325

DOI: $10.35429 / E J R P .2019 .9 .5 .24 .37$

Received July 05, 2019; Accepted November 25, 2019

\begin{abstract}
The remainance and development in the market depend, among other factors, on the quality of sold products or provided services, which is a situation of concern in sectors such as tourism where globalization demands first level services, as is the case in the city of Campeche, where businessmen are investing in hotel infrastructure according to the colonial characteristics of the town. The research's objective is to identify the incidence of leadership in the quality of services under the perception of hotel managers as responsible for the operability results. This research is a descriptive type with non-experimental transversal design, with a enumerated population; the results obtained through the quality and leadership indexes indicate that, contrary to expectations, managers consider that the provided services don't have an adequate level of quality, and the design of new strategies is needed to improve the processes under the transformational leadership which must face problems with opportunity in order to innovate in the services of the market where they participate.
\end{abstract}

\begin{tabular}{llll}
$\begin{array}{l}\text { Knowledge management, Open innovation, } \\
\text { Leadership }\end{array}$ & $\begin{array}{l}\text { Gestión del conocimiento, Innovación abierta, } \\
\text { Liderazgo }\end{array}$ \\
\hline
\end{tabular}

Citation: ARREDONDO-SAFA, Judith, PEREZ-ROMERO, Luis Alfonso and CASTRO-VALENCIA, Alberto Merced. Study on knowledge management and open innovation. ECORFAN Journal-Republic of Peru. 2019. 5-9: 24-37.

\begin{abstract}
Resumen
La presente investigación tiene como objetivo evaluar empíricamente las variables que impactan a la gestión del conocimiento y a su vez, como dicha gestión incide en los procesos de innovación abierta. Para ello, Para ello, se conduce una investigación cuantitativa no experimental, transversal y correlacional que permita la obtención de resultados exploratorios a partir del análisis estadístico inferencial. Se ha aplicado una prueba piloto con un instrumento de 60 ítems configurado en escala de Likert en 5 tipos de organizaciones del sector agroindustrial del estado de Jalisco, aplicado a directores involucrados en los procesos de innovación. Lo anterior con base en los trabajos de (Martínez - Conesa, 2017), (Popa et al. 2016), (Chang et al, 2011), (Collins \& Smith, 2006), entre otros. Con los resultados obtenidos se ha podido confirmar la validez de criterio y de constructo del instrumento y a su vez, la comprobación de las correlaciones entre las variables. Asimismo, la existencia de un modelo teórico consistente a través del análisis factorial y de las matrices de correlaciones de Pearson. Con los resultados obtenidos se busca coadyuvar en el diseño de estrategias que promuevan la Innovación Abierta en las organizaciones como una ventaja competitiva que promueve el desarrollo multisectorial.
\end{abstract}

Gestión del conocimiento, Innovación abierta, Liderazgo

* Correspondence to Author (email: judith.arredondo@edu.uag.mx)
$\dagger$ Researcher contributing first author. 


\section{Introduction}

At the end of the s. XX organizations began to rethink their strategies for the generation and transfer of knowledge. The above through the impulse of open and collaborative processes that involve the participation of the actors involved in the recently named Quintuple Helix of Innovation which integrates private companies, government, universities, civil society and socio-environmental systems. (Baccarne \& Logghe, 2016). In this sense, knowledge management has become a fundamental practice for the generation of added value in an environment in constant transformation and change (Nonaka, 2000, Hana, 2013, Wu, 2014). Knowledge management is a fundamental piece for innovation processes, by using existing knowledge, either tacitly or explicitly, and combining it in different ways to create new products or services ( $\mathrm{Wu} \& \mathrm{Hu}, 2018)$. In this sense, innovation can be consolidated through closed or open processes, the latter being the one that promotes the active exchange of knowledge from the organization abroad and vice versa.

The main thinkers of the open innovation model (Chesbrough, 2006), (Von Hippel, 2005), (Echeverria, 2003), (Silverstone, 1993) (Winter, 2001), were based on the Theories of Knowledge Management of such authors like Nonaka and Takeuchi (1995), Druker (1994), Polanyi (1997), Alavi and Leideer (1999), among others, who promote collective learning generated from inter-institutional participation. This process assumes that strategic collaboration between government, private initiative, civil society and Higher Education Institutions offers competitive advantages to those involved in sharing resources, risks and disruptive ideas.

The present research seeks to assess in a theoretical and empirical way what are the variables that impact the management of knowledge of organizations, particularly through the variables leadership and organizational culture and in turn, how such management affects the processes of open innovation in its two dimensions: inbound knowledge flows (outbound) and outbound knowledge flows. These phenomena are fundamental elements to increase the productivity of organizations and, consequently, are natural promoters of the well-being of society. The initial questions asked are: How does knowledge management impact on open innovation processes?
Is this a linear or exponential process based on obtaining, storing, interpreting and applying knowledge? What are the variables that impact these phenomena?, particularly leadership and organizational culture. The formulation of these questions is not only pertinent but pressing in the Mexican context. In the last two decades, the economy has not grown significantly due, among other causes, to low productivity, insufficient technological innovation, lack of clear public policies and the limited investment that exists for knowledge generation. (González Santoyo \& Flores Romero, 2018). In developed countries, innovation can explain at least two thirds of its growth rate being, in addition, the result of coordinated work between the various sectors that make up society (Ahuja Sánchez \& Pedroza, 2011). During the past 35 years, Mexico has invested less than $0.5 \%$ of GDP in researchoriented activities and knowledge generation when on average, all the countries of the Organization for Economic Cooperation and Development (OECD) on average allocate $2.08 \%$ of its GDP (González Santoyo \& Flores Romero, 2018). Another fundamental indicator is the recent publication of the international innovation ranking that the WIPO (World Intellectual Property Organization) elaborates year after year, together with Cornell SC Jonhson College of Busuness and INSEAD. Through an index of 100 points, 126 most important economies in the world are qualified to know the general state that keeps its capacity for innovation. Mexico ranks 56th with 35.34 points, below countries like Costa Rica, Serbia or Mongolia, to name a few examples. The present investigation seeks to contribute to shorten the aforementioned gap from a relational-causal perspective and with a multisectoral approach. Open innovation has proven effective as a formula for generating value that positively impacts local, regional and global development.

\section{Theoretical framework}

Knowledge Management in Organizations of S. XXI

Peter Drucker introduced the concept of "knowledge companies" in 1994, who considered that, in this society, knowledge is the primary resource for the individual and for the economy as a whole (Drucker, 2006).

ARREDONDO-SAFA, Judith, PEREZ-ROMERO, Luis Alfonso and CASTRO-VALENCIA, Alberto Merced. Study on knowledge management and open innovation. ECORFAN Journal-Republic of Peru. 2019 
This author points to scientists as knowledge workers who are becoming the center of gravity of the working population. The challenge is to manage the work of these teams in an efficient way. According to Nonaka and Takeuchi (2013), knowledge is created through human interactions, through dynamic processes that help create the future. By its very nature, knowledge becomes obsolete one minute after it has been created. Knowledge, for the authors, is the guide to generate strategies that lead organizations to their own well-being and that of society (Takeuchi, 2013).

Knowledge is the rationalization of the information obtained from the surrounding world derived from experience, search and reflection (Lovera Aguilar, 2009). This part of obtaining information, which is classified and interpreted so that it can then become knowledge. For Muñoz and Riverola (2003) it is the ability to solve a certain set of problems (Valencia Rodríguez, 2009). According to Alavi and Leider (1999), information is converted into knowledge once it is processed in the minds of individuals and knowledge becomes information once it is articulated and presented in the form of text, graphics and words or other forms. symbolic In this way, a virtuous circle is generated that gives organizations the possibility of reinventing themselves and anticipating market needs.

Theories of knowledge have been approached in at least three dimensions: epistemological, ontological and time, whose fusion during the process of knowledge creation originates innovation in order to make a more competitive organization in its natural environment ( Lovera Aguilar, 2009). The time dimension refers to the stages through which knowledge produces the conversion of knowledge for strategic purposes. From an epistemological perspective, knowledge is classified by authors such as Polanyi (1966), Nonaka and Takeuchi (1995) as tacit and explicit, being the first one that is poorly codified and cannot be formally communicated. It originates from human experiences and their perception of the facts. Instead, explicit knowledge can be transferred through formal communication because it is articulable and codifiable.
On the other hand, the ontological vision of knowledge focuses on identifying the entities that create knowledge, whether individual, group, organizational or inter-organizational. The ontological perspective is translated into an organization when it defines its mission, vision and values. Essers and Schreinemakers (1997) have stated that the Nonaka model does not take into consideration that the capacities of an organization not only depend on the ideas and beliefs of its members, nor does it recognize the discrepancies between the ideas and proposals of the different subgroups of the same. Likewise, Bereiter (2002) also states that Nonaka does not explain the way in which ideas originate or the way in which they deepen them. Cited by (Gil \& Carrillo, 2013). What can be affirmed for the purposes of this research is that an organization manages its knowledge based on the learning of its members, who are responsible for generating added value by transforming information into applied innovation. Knowledge becomes the most powerful weapon to flexibly face the demands of the market. Managing knowledge is also managing its effectiveness in achieving strategic goals and projects. This process results from the integration of knowledge of the members of an organization in order to innovate.

New knowledge becomes part of dynamic competencies as an added value of the organization. (Lovera Aguilar, 2009). For authors such as (Wu \& Hu, 2018), this set of processes can be synthesized in four dimensions: the acquisition, transfer, integration and application of knowledge, having both internal and external sources to the organization.

Knowledge management should not be seen as an end in itself, but as a tool that, when properly utilized, helps the organization achieve the strategic objectives that have been imposed. It is an essential part of every intelligent organization, being defined as one that is capable of effectively integrating perception, knowledge creation and decision making (Chun Wei Choo, 1998). Once the knowledge is generated, the organization must transfer it, this process is called knowledge transfer. It is said that the process of knowledge transfer is linked to the learning capacity of the organization and its openness to strategically link with other social actors. Intersectoral linking and relational capital are fundamental to the open innovation process that is the object of study of this research, so it will deepen its theoretical conceptualization. 
In particular, reference is made to the work of (Martínez Conesa, Soto Acosta, \& Carayannis, 2017), who carried out a quantitative investigation in Spain in 2016, focused on small and medium-sized companies in the manufacturing sector. In their theoretical model, they stated that information technologies, interdepartmental interconnection and human resources practices are fundamental factors that influence knowledge management. They also proposed conducting a confirmatory investigation in a different geographical context and in a particular sector. The above to be able to make generalizations. As a result of their findings, they suggested incorporating two additional factors in future research: organizational culture and leadership, both taken into account in the proposed theoretical model.

The relationship between leadership and knowledge management was raised by authors such as (Koohang, 2016), (Parmar, 2015), (Ren - Zong, Kuo et al. 2011), (Yew Wong et al, 2005), among others, where it is proven that the degree of openness of leaders to provide employees with opportunities for strategic decision making, has a positive impact on the exchange and generation of knowledge. On the other hand, the influence of organizational culture on knowledge management has been studied by authors such as Alvi and Leider (2006), De Long (2000), Gold (2001), among others and verified by empirical authors such as (Stock, McFadden, \& Gowen, 2010). The latter managed to statistically verify this relationship through a study of 371 hospitals in the United States. For this they used four dimensions for organizational culture (group culture, development culture, rational culture and hierarchical culture). In turn, knowledge management was measured in three dimensions: acquisition, dissemination and responsiveness. Additionally (Akhavan \& et al., 2014) also verified this relationship through a quantitative study in Iran in which 276 companies from various industries participated. They used four dimensions of organizational culture (cooperation, innovation, consistency and effectiveness) and four of knowledge management (generation, organization, dissemination and application). Their findings establish that an organization with a flexible and innovative culture directly and significantly impacts knowledge management.
That said, it is established as initial hypotheses that:

- H1. There is a significant and positive relationship between leadership and knowledge management of organizations.

- H2. There is a significant and positive relationship between organizational culture and knowledge management of organizations.

\section{The process of Innovation in organizations.}

Since the 20th century, innovation was conceived exclusively by technological advances that added value to the production process. The author Schumpeter (1950) pioneered expanding the scope of this concept by mentioning that innovation consists not only of new products and processes, but also of new forms of organization, new markets and new sources of raw materials (Ortíz Cantú \& Pedroza Zapata, 2006).

During the last century, innovation evolved significantly. In the 50s, organizations concentrated their efforts towards the search for operational and administrative efficiencies. In the 60 's, this process focused on improving a product or service through the company's internal resources. This resulted in better quality or a reduction in operating costs. During the 80 's, innovation was the result of technological changes and the organization's interactions with other strategic actors. It was in the decade of the 90 's when innovation is complexed and questioned by raising an obvious dichotomy between the need of organizations to promote a disruptive force of innovation and, on the other hand, maintain a certain degree of stability in the processes and structures to guarantee its growth and permanence (Hung, 2004).

In 1992 the Oslo Manual was created, which proposed a system of innovation indicators that, together with the Frascati Manual on Research and Development (R\&D) activities, became an international canon for measuring innovation (Echeverría, 2008). After its publication and in 1997, the second edition that incorporates into the services sector is printed so that finally in 2005, marketing innovation and organizational innovation are added. 
The Oslo Manual states that innovation is the introduction of a new or significantly improved product or service, a process or a new marketing method or a new organizational method, in the internal practices of the company, the organization of the place of work or external relations. (Organization for Economic Cooperation and Development (OECD) and Eurostat, 2018). This Manual affirms that innovation is not an end in itself, but a means for growth in production and productivity; It also contributes to increasing the competitiveness of a company and being present in new markets (Echeverría, 2008). López, N., Montes, and Vázquez (2003), define innovation as a set of activities within companies, which contribute to generate new technological knowledge or improve the use of existing ones. This knowledge is applied to obtaining new goods and services, as well as new forms of production. (Mathison \& Gándara, 2007).

Open innovation is a strategic concept that revolutionizes the innovation process. The idea of opening the frontiers of organizations to develop competitive advantages has been a topic of interest for both their managers and the academic community (Schneckenberg, 2015). The innovation process can be carried out within the organization in a closed environment or it can be driven together with other market entities. The first refers to the integration of innovation processes vertically, through the development of research activities within the organization, promoting the development of products and services that are developed and marketed by the organization itself (San Martín Albizuri \& Rodríguez Castellanos, 2012). Closed innovation systems were born as departments or working groups within companies. Instead, the second refers to open innovation that presupposes that the true value of innovation lies in the synergies that are established with the value chain and other strategic actors in society. This is mainly due to the need to shorten $R \& D$ cycles, reduce costs and give greater mobility to creative agents.

Open innovation proposes a new paradigm, a concept coined by Chesbrough (2003) who postulates the need to establish internal and external knowledge flows by organizations to extract the greatest possible value from their innovative potential (González Sánchez \& García Muiña, 2011).
Chesbrough (2006) defines open innovation as the use of internal and external flows of knowledge in a certain way to accelerate internal innovation and expand markets for the external use of innovation respectively. (González Sánchez \& García Muiña, 2011). Open innovation is seen as a strategy to accelerate the process of learning and knowledge generation of organizations based on the complementarity of acquired experiences. This is a dynamic process that assumes the existence of at least three phenomena (Gassmann et al. 2004): The first called "Outside in" which refers to the flow of knowledge that enters the innovation process of an organization from outside.

The second "Inside out", which involves the marketing of ideas and technology from the organization to the market; and finally the "coupled process" that promotes the establishment of an innovation routine within organizations while establishing strategic partners and alliances during the process. In this sense, innovation systems can be considered as sets of different institutions and social actors that, both by their individual action and by their interrelations, contribute to the creation, development and dissemination of new productive practices (Albornoz, 2009). As the author mentions, this practice can be articulated in virtuous circles, reinforcing each other in the promotion of learning and innovation processes.

The deserters of this theory mention that closed innovation is the best way to maintain the competitive advantages of the organization (García Muiña 2007), however, the 21st century demands openness and such opening must be accompanied by protection mechanisms. As he puts it (Hurmelinna-Laukkanen \& Ritala, 2010), the signing of contracts could be a natural form of protection for the parties involved, but it is not the only one.

The proper administration of human resources also plays a fundamental role, conserving strategic collaborators and promoting a culture of respect for the handling of sensitive information. 
The relationship between knowledge management and innovation has been studied by authors such as (Wang, 2018), (Martínez Conesa, Soto Acosta, \& Carayannis, 2017), (Soto-Acosta et al, 2018), (Ing-Long, et al , 2018), (Bican et al, 2017), (Chung-Jen et al., 2010), (Darroch et al, 2002), among others, where the relationship between the management capacity of the knowledge of an organization and the innovation practices implemented. If so, it seeks to show that:

- H3. There is a significant and positive relationship between knowledge management capacity and open innovation in an organization in its two dimensions: incoming and outgoing knowledge flows.

\section{Theoretical Research Model.}

Based on a review of the state of the art, the following theoretical model is proposed (Figure 1), which is made up of four fundamental variables: leadership, organizational culture, knowledge management and open innovation in its two dimensions: Incoming knowledge flows (inbound) and outbound knowledge flows

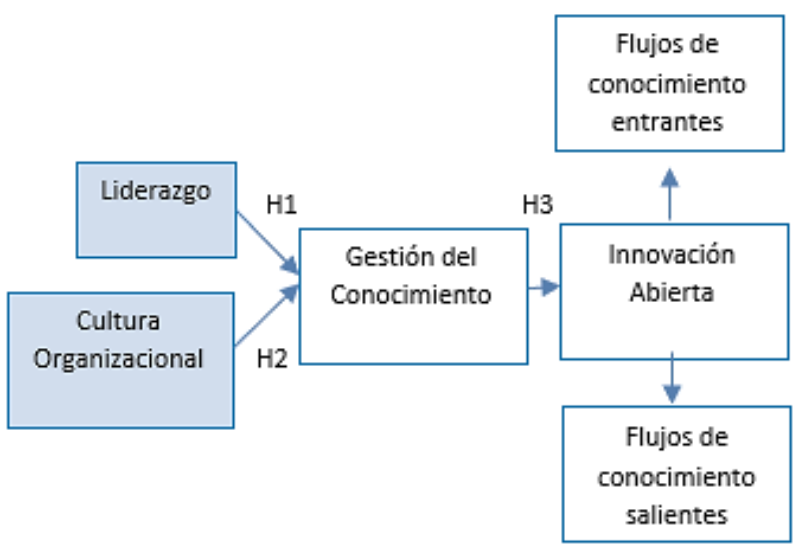

Figure 1 Proposed Theoretical Model

Source: own elaboration, adapted from (Martínez Conesa, Soto Acosta, \& Carayannis, 2017)

As a theoretical contribution, we seek to contribute to the state of the art by generating a theoretical discussion on Knowledge Management, Open Innovation from a different geographical context and applied to a particular sector. Likewise, a methodological contribution will be sought when proposing an instrument based on various authors, as shown in Table 1 Methodological Matrix, used for the pilot approach.
As an empirical contribution, we will seek to demonstrate statistically the relationship between the variables leadership, organizational culture, knowledge management and open innovation and, in turn, provide knowledge with the findings found. As a practical contribution, we will seek to contribute to the design of strategies that promote Knowledge Management and Open Innovation, in organizations with the purpose of contributing to local, regional and national development.

\begin{tabular}{|c|c|c|c|}
\hline Construct & Based on: & Items & $\begin{array}{c}\text { Instrument } \\
\text { Used }\end{array}$ \\
\hline $\begin{array}{l}\text { DEPENDENT } \\
\text { VARIABLE: } \\
\text { Knowledge } \\
\text { Management, }\end{array}$ & \multirow{2}{*}{$\begin{array}{l}\text { Martínez } \\
\text { Conesa, Isabel, } \\
\text { Soto Acosta, } \\
\text { Pedro, George } \\
\text { Carayannis, } \\
\text { Elías, "On the } \\
\text { path towards } \\
\text { open } \\
\text { innovation: } \\
\text { assessing the } \\
\text { role of } \\
\text { knowledge } \\
\text { management } \\
\text { capability and } \\
\text { environmental } \\
\text { dynamism in } \\
\text { SMEs", Journal } \\
\text { of Knowledge } \\
\text { Management, } \\
\text { Vol. 21, No. 3, } \\
\text { 2017, pp 553- } \\
\text { 570 }\end{array}$} & $\begin{array}{l}\text { GDC1, } \\
\text { GDC2, } \\
\text { GDC3, } \\
\text { GDC4, } \\
\text { GDC5, } \\
\text { GDC6, } \\
\text { GDC7, } \\
\text { GDC8, } \\
\text { GDC9 }\end{array}$ & (Liao, 2011) \\
\hline $\begin{array}{l}\text { DEPENDENT } \\
\text { VARIABLE: } \\
\text { Open } \\
\text { Innovation }\end{array}$ & & $\begin{array}{l}\text { INA1, } \\
\text { INA2, } \\
\text { INA3, } \\
\text { INA4, } \\
\text { INA5, } \\
\text { INA6, } \\
\text { INA7, } \\
\text { INA8 }\end{array}$ & $\begin{array}{l}\text { (Chen and } \\
\text { Shui, 2015) }\end{array}$ \\
\hline $\begin{array}{l}\text { INDEPENDE } \\
\text { NT } \\
\text { VARIABLE: } \\
\text { Leadership }\end{array}$ & $\begin{array}{l}\text { Zong-Ren, } \\
\text { Kuo, el tal, } \\
\text { "The impact of } \\
\text { empowering } \\
\text { leadership for } \\
\text { KMS adoption, } \\
\text { Management } \\
\text { Decision, Vol. } \\
\text { 49, No. 7, 2011 } \\
\text { p.p. 1120-1140 }\end{array}$ & $\begin{array}{l}\text { LIE1, } \\
\text { LIE2, } \\
\text { LIE3, } \\
\text { LIE4 }\end{array}$ & $\begin{array}{l}\text { (Ahearne et al, } \\
\text { 2005; Arnold et } \\
\text { al., 2000; } \\
\text { Martin \& Bush, } \\
\text { 2006) }\end{array}$ \\
\hline $\begin{array}{l}\text { INDEPENDE } \\
\text { NT } \\
\text { VARIABLE: } \\
\text { Organizational } \\
\text { Culture, }\end{array}$ & $\begin{array}{l}\text { Stock, Gregory } \\
\text { et al. } \\
\text { "Organizationa } \\
\text { 1 Culture, } \\
\text { Knowledge } \\
\text { management } \\
\text { and Patient } \\
\text { Safety in US } \\
\text { Hospitals", The } \\
\text { Quality } \\
\text { Management } \\
\text { Journal, Vol. } \\
\text { 17, No. 2, } \\
\text { 2010, p.p. 7-26 }\end{array}$ & $\begin{array}{l}\text { CUO1, } \\
\text { CUO2, } \\
\text { CUO3, } \\
\text { CUO4, } \\
\text { CUO5, } \\
\text { CUO6, } \\
\text { CUO7, } \\
\text { CUO8, } \\
\text { CUO9, } \\
\text { CUO10, } \\
\text { CUO11, } \\
\text { CUO11, } \\
\text { CUO12 }\end{array}$ & $\begin{array}{c}\text { (Cameros \& } \\
\text { Quinn, 1999) }\end{array}$ \\
\hline
\end{tabular}

Table 1 Methodological Matrix

Source: authorship (2018) 


\section{Investigation methodology}

As mentioned, this research aims to empirically evaluate the variables that impact knowledge management and open innovation processes of organizations.

In particular, leadership and organizational culture will be analyzed as two factors of the organization that can be catalysts or obstacles for the generation, exchange and application of knowledge in innovation processes.

The purpose is to prepare a confirmatory analysis of these factors in a specific geographical context and in a particular sector in order to raise generalizations.

It will also seek to understand what the relationship between knowledge management and innovation is.

The latter demands the adequate interpretation and use of knowledge to propose new or significantly improved products or services, processes or organizational structures.

For this, a quantitative, nonexperimental, cross-sectional, correlationalcausal investigation has been proposed that allows obtaining confirmatory results from an inferential statistical analysis.

During the piloting, an instrument configured in a 5-point Likert scale was used (never, rarely, occasionally, frequently and always). The leadership variable was measured through 4 items designed based on (Ahearne et al, 2005; Arnold et al., 2000; Martin \& Bush, 2006).

The organizational culture variable was measured in 12 items proposed by (Cameros \& Quinn, 1999). Knowledge management was integrated by 9 items based on (Liao, 2011) and open innovation was measured with 8 items designed by (Chen and Shui, 2015).

\begin{tabular}{|c|c|c|}
\hline Variable & $\begin{array}{c}\text { Operational } \\
\text { Definition }\end{array}$ & $\begin{array}{c}\text { Cronbach's } \\
\text { Alpha }\end{array}$ \\
\hline $\begin{array}{l}\text { Knowledge } \\
\text { Management }\end{array}$ & $\begin{array}{l}\text { It refers to the ability } \\
\text { of the organization } \\
\text { to create, store, } \\
\text { exchange and apply } \\
\text { relevant knowledge } \\
\text { that facilitates the } \\
\text { processes of product } \\
\text { or service } \\
\text { innovation. }\end{array}$ & .820 \\
\hline Open Innovation & $\begin{array}{l}\text { It refers to the ability } \\
\text { of an organization to } \\
\text { obtain and explore } \\
\text { knowledge } \\
\text { generated by } \\
\text { external interest } \\
\text { groups such as } \\
\text { suppliers, } \\
\text { customers, } \\
\text { competitors, among } \\
\text { others, as well as the } \\
\text { exploitation of ideas } \\
\text { generated within the } \\
\text { organization, such } \\
\text { as licensing, the sale } \\
\text { of knowledge, the } \\
\text { creation of new } \\
\text { signatures, etc. }\end{array}$ & .757 \\
\hline Leadership & $\begin{array}{l}\text { It refers to the } \\
\text { degree of openness } \\
\text { of leaders to provide } \\
\text { employees with } \\
\text { opportunities for } \\
\text { strategic decision } \\
\text { making. Likewise, } \\
\text { to promote a culture } \\
\text { that facilitates the } \\
\text { obtaining } \\
\text { information, of } \\
\text { classification, } \\
\text { interpretation and } \\
\text { application in the } \\
\text { processes } \\
\text { innovation of } \\
\text { products of } \\
\text { services. }\end{array}$ & .854 \\
\hline $\begin{array}{l}\text { Organizational } \\
\text { culture }\end{array}$ & $\begin{array}{l}\text { It refers to the set of } \\
\text { values, beliefs and } \\
\text { assumptions that } \\
\text { members of an } \\
\text { organization have in } \\
\text { common. It seeks to } \\
\text { identify the type of } \\
\text { culture that most } \\
\text { drives the exchange } \\
\text { of knowledge and } \\
\text { innovation. }\end{array}$ & .799 \\
\hline
\end{tabular}

Table 2 Summary of validity and reliability of the Instrument

* Format proposed by (Pérez Romero, 2018)

The instrument was sent to 80 subjects belonging to the 5 types of organizations (companies, government agencies, universities, research centers and chambers or associations) in November 2018. 
A response of $72 \%$ was obtained. The preliminary results are presented below. It should be noted that the highest number of responses obtained was from private companies (36.5\%), followed by Higher Education Institutions (17.5\%). The initial investigation was carried out in the state of Jalisco, Mexico, in the context of the agri-food industry. This industry is the one that generates the greatest value of GDP, within the Jalisco manufacturing industry sector, since it contributes $28 \%$ of the total amount derived from manufacturing (SAGARPA, 2017). Currently, there are 10,794 Jalisco companies that participate in this industry that have a presence in 69 countries of the world and on all continents, through the commercialization of a great diversity of products (SAGARPA, 2017). As a research unit, it was proposed to the Directors or Managers, as well as people directly involved in the innovation processes of the organizations. Likewise, the central actors that are part of the agri-food value chain were included.

\section{Results and Discussion}

The results obtained during the piloting were captured in a database in SPSS version 24. First, an outlier analysis was carried out that resulted in the need to eliminate 17 respondents, leaving a database of 41 instruments. With this database, reliability, normality and linearity analyzes were carried out. The most widely used measure of reliability is Cronbach's Alpha (Hair \& et al., 1999). According to that author, the general agreement on the lower limit of the Alpha is .70, although it may fall to .60 in exploratory investigations.

\begin{tabular}{|l|r|}
\hline \multicolumn{1}{|c|}{ Variable } & Alpha \\
\hline LIE & .854 \\
\hline CUO & .799 \\
\hline GDC & .820 \\
\hline INA Inbound & .803 \\
\hline INA Outbound & .757 \\
\hline
\end{tabular}

Table 3 Cronbach's Alpha Analysis

Source: own elaboration (2019)

As can be seen in the table, the variables showed a reasonable behavior with values above the .60 indicated by (Hair \& et al., 1999). Subsequently, the normality tests were carried out, which are summarized in the following table.
The data obtained by the analysis of asymmetry and kurtosis are among the ranges of +-2 points, with the exception of the item CUO3, which yielded a result outside any accepted range: 7.94. This item should be carefully reviewed before the application of the final instrument. In the case of the Shapiro Wilk test, no results greater than 0.05 were obtained, which means that its distribution is normal. In the KMO tests (Kaiser-Meyer-Olkin), the variables obtained scores higher than 0.5 being suitable for factor analysis (See table 4)

\begin{tabular}{|l|r|r|}
\hline \multicolumn{1}{|c}{ Dimension } & \multicolumn{1}{c|}{ KMO } & \multicolumn{1}{c|}{ SIG } \\
\hline LIE & .788 & .000 \\
\hline CUO & .654 & .000 \\
\hline GDC & .562 & .000 \\
\hline INA & .796 & .000 \\
\hline
\end{tabular}

Table 4 KMO Analysis

Source: own elaboration (2019)

Being results obtained from a 5-point Likert scale, normality represents a challenge due to the short margin of variability that this type of measurement offers. Likewise, linearity tests were carried out, in which the relationships between the Open Innovation and Knowledge Management variables showed a result of less than 0.5 .

One of the possible solutions to these results is to transform one or both variables to achieve linearity, that is, the creation of a new variable that represents the non-linear part of the relationship (Hair \& et al., 1999).

Subsequently, the exploratory factor analysis was carried out, which is a multivariate statistical technique that is incorporated into the quantitative methodology that involves latent or unobservable variables that cannot be measured directly (Zamora, 2009). After running this test (See Table 5), it has been possible to confirm the existence of three clearly defined factors, these being leadership, organizational culture and knowledge management. The extraction method used is the analysis of main components, the rotation method is varimax with Kaiser normalization. 


\begin{tabular}{|l|r|r|r|}
\hline \multicolumn{1}{|c|}{$\mathbf{1}$} & \multicolumn{1}{c|}{$\mathbf{2}$} & \multicolumn{1}{c|}{$\mathbf{3}$} \\
\hline LIE1 & 0.862 & & \\
\hline LIE2 & 0.872 & & \\
\hline LIE3 & 0.761 & & \\
\hline LIE4 & 0.640 & & \\
\hline CUO3 & & 0.637 & \\
\hline CUO9 & & 0.667 & \\
\hline CUO8 & & 0.856 & \\
\hline CUO10 & & 0.837 & \\
\hline GDC3 & & & 0.585 \\
\hline GDC4 & & & 0.747 \\
\hline GDC8 & & & 0.716 \\
\hline GDC9 & & & 0.822 \\
\hline
\end{tabular}

Table 5 Rotated component matrix: Leadership, Organizational Culture and Knowledge Management Source: own elaboration (2019)

Finally, the same exercise was run for the open innovation variable, being able to confirm the two dimensions indicated in the state of the art (incoming information flows and outgoing information flows) - See Table 6.

The component analysis extraction method was used main and as a Varimax rotation method with Kaiser normalization.

\begin{tabular}{|l|r|r|}
\hline \multicolumn{2}{|c|}{1} & \multicolumn{2}{c|}{$\mathbf{2}$} \\
\hline INA1 & & 0.920 \\
\hline INA2 & & 0.817 \\
\hline INA3 & 0.855 & 0.582 \\
\hline INA5 & 0.785 & \\
\hline INA6 & 0.686 & \\
\hline INA7 & & \\
\hline
\end{tabular}

Table 6 Rotating component matrix: Open Innovation Source: own elaboration (2019)

To address the relationships raised in the theoretical model, bivariate correlation matrices were developed, a useful technique to identify relationships between multiple variables and to identify whether these relationships are weak or strong (Hair \& et al., 1999).

For the Leadership and Organizational Culture variables and their impact on Knowledge Management, the results shown in Tables 7 and 8 confirmed the relationship between them and support hypotheses 1 and 2 .

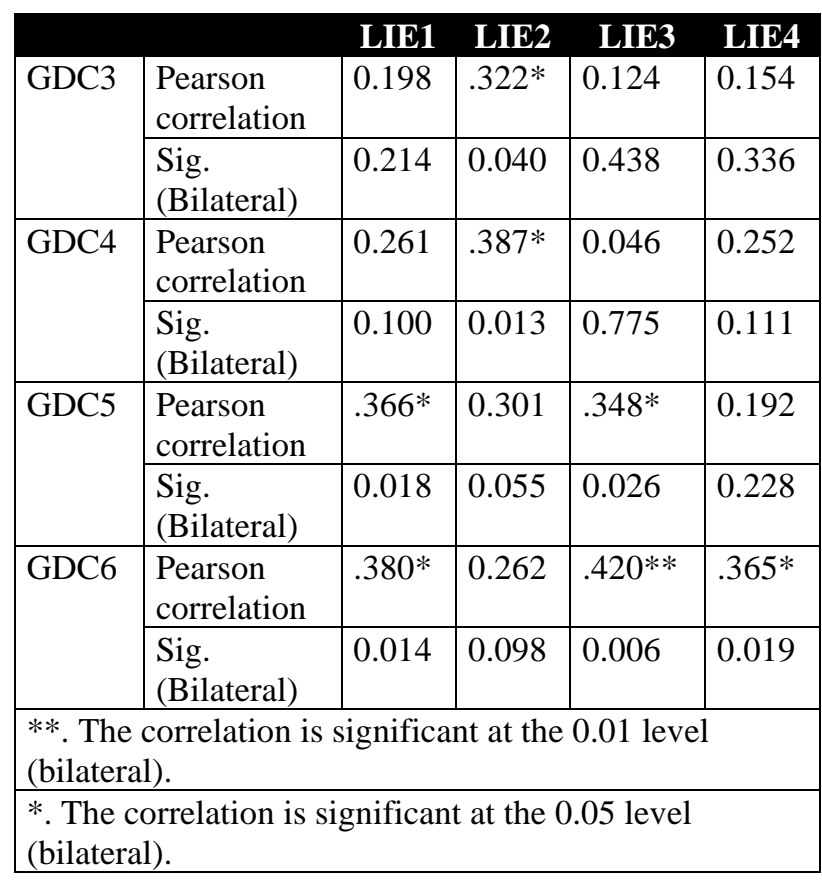

Table 7 Correlations between Knowledge Management and Leadership

Source: own elaboration (2019)

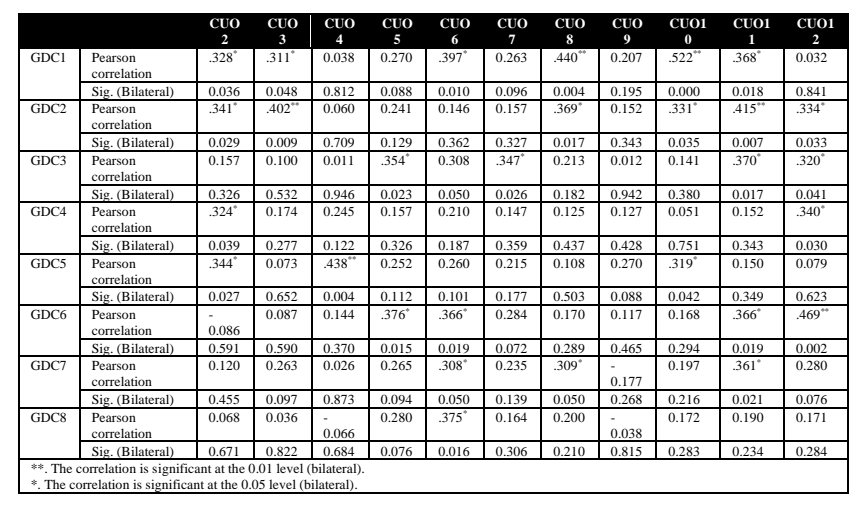

Table 8 Correlations between Knowledge Management and Organizational Culture

Source: own elaboration (2019)

In the case of the variables Knowledge Management and Open Innovation, the results shown in Table 9 confirmed a significant relationship ( $\mathrm{p}<.01)$, thus strengthening hypothesis 3 . 


\begin{tabular}{|c|c|c|c|c|c|}
\hline & GDC6 & GDC7 & GDC8 & GDC9 \\
\hline \multirow[t]{2}{*}{ INA1 } & $\begin{array}{l}\text { Pearson } \\
\text { correlation }\end{array}$ & $.482^{* *}$ & $.602^{* *}$ & $.527^{* * *}$ & $.381^{*}$ \\
\hline & $\begin{array}{l}\text { Sig. } \\
\text { (Bilateral) }\end{array}$ & 0.001 & 0.000 & 0.000 & 0.014 \\
\hline \multirow[t]{2}{*}{ INA2 } & $\begin{array}{l}\text { Pearson } \\
\text { correlation }\end{array}$ & $.521^{* *}$ & $.566^{* *}$ & $.493^{* *}$ & 0.177 \\
\hline & $\begin{array}{l}\text { Sig. } \\
\text { (Bilateral) }\end{array}$ & 0.000 & 0.000 & 0.001 & 0.269 \\
\hline \multirow[t]{2}{*}{ INA3 } & $\begin{array}{l}\text { Pearson } \\
\text { correlation }\end{array}$ & $.466^{* * *}$ & $.353^{*}$ & $.578^{* *}$ & $.456^{\text {** }}$ \\
\hline & $\begin{array}{l}\text { Sig. } \\
\text { (Bilateral) }\end{array}$ & 0.002 & 0.024 & 0.000 & 0.003 \\
\hline \multirow[t]{2}{*}{ INA6 } & $\begin{array}{l}\text { Pearson } \\
\text { correlation }\end{array}$ & 0.225 & $.374^{*}$ & 0.271 & 0.259 \\
\hline & $\begin{array}{l}\text { Sig. } \\
\text { (Bilateral) }\end{array}$ & 0.158 & 0.016 & 0.087 & 0.102 \\
\hline \multirow[t]{2}{*}{ INA7 } & $\begin{array}{l}\text { Pearson } \\
\text { correlation }\end{array}$ & $.320^{*}$ & $.331^{*}$ & $.310^{*}$ & 0.038 \\
\hline & \begin{tabular}{|l|} 
Sig. \\
(Bilateral) \\
\end{tabular} & 0.042 & 0.034 & 0.049 & 0.811 \\
\hline \multicolumn{6}{|c|}{$\begin{array}{l}\text { **. The correlation is significant at the } 0.01 \text { level } \\
\text { (bilateral). } \\
\text { *. The correlation is significant at the } 0.05 \text { level } \\
\text { (bilateral). }\end{array}$} \\
\hline
\end{tabular}

Table 9 Correlations between Knowledge Management and Open Innovation

Source: own elaboration (2019)

\section{Annexes}

Next, the items used during piloting (Table 10)

\begin{tabular}{|c|c|}
\hline INA1 & $\begin{array}{l}\text { In our innovation projects we involve external } \\
\text { partners such as clients, competitors, research } \\
\text { centers, government, consultants or universities. }\end{array}$ \\
\hline INA2 & $\begin{array}{l}\text { Our innovation projects are highly dependent on } \\
\text { the contributions of external partners such as } \\
\text { customers, competitors, research centers, } \\
\text { government, consultants or universities. }\end{array}$ \\
\hline INA3 & $\begin{array}{l}\text { Our organization buys Research and } \\
\text { Development services from external partners. }\end{array}$ \\
\hline INA4 & $\begin{array}{l}\text { Our organization frequently buys intellectual } \\
\text { property such as patents, copyrights, registered } \\
\text { trademarks and others from external partners to } \\
\text { boost our innovation projects. }\end{array}$ \\
\hline INA5 & $\begin{array}{l}\text { Our organization sells to third parties licenses, } \\
\text { such as patents, copyrights, trademark } \\
\text { registrations or others to benefit from our } \\
\text { innovation efforts. }\end{array}$ \\
\hline INA6 & $\begin{array}{l}\text { Our organization frequently signs royalty } \\
\text { contracts with other organizations to benefit its } \\
\text { innovation projects. }\end{array}$ \\
\hline INA7 & $\begin{array}{l}\text { Our organization promotes every possible use of } \\
\text { its intellectual property for its own benefit. }\end{array}$ \\
\hline INA8 & $\begin{array}{l}\text { Our organization invests in companies of recent } \\
\text { creation, with high content of innovation for its } \\
\text { own benefit. }\end{array}$ \\
\hline GDC1 & $\begin{array}{l}\text { The organization creates new knowledge that is } \\
\text { permeated to the different areas or departments } \\
\text { of the company. }\end{array}$ \\
\hline GDC2 & $\begin{array}{l}\text { The organization creates new operating systems } \\
\text { that permeate the different areas or departments } \\
\text { of the company. }\end{array}$ \\
\hline GDC3 & $\begin{array}{l}\text { The organization creates management policies } \\
\text { and processes that permeate the different areas of } \\
\text { the company. }\end{array}$ \\
\hline
\end{tabular}

\begin{tabular}{|c|c|}
\hline GDC4 & $\begin{array}{l}\text { The organization is committed to sharing } \\
\text { knowledge with all its areas or departments. }\end{array}$ \\
\hline GDC5 & $\begin{array}{l}\text { The organization designs activities to share } \\
\text { information with all its areas or departments. }\end{array}$ \\
\hline GDC6 & $\begin{array}{l}\text { The organization integrates different sources of } \\
\text { information and knowledge through its areas or } \\
\text { departments. }\end{array}$ \\
\hline GDC7 & $\begin{array}{l}\text { The organization engages in technology transfer } \\
\text { processes to its employees regardless of their } \\
\text { area or department. }\end{array}$ \\
\hline GDC8 & $\begin{array}{l}\text { The organization is involved in processes to } \\
\text { apply knowledge experimentally in all its areas } \\
\text { or departments. }\end{array}$ \\
\hline GDC9 & $\begin{array}{l}\text { The organization is involved in processes to } \\
\text { apply knowledge oriented to solve problems in } \\
\text { all its areas or departments. }\end{array}$ \\
\hline LIE1 & $\begin{array}{l}\text { The leaders respect the opinion of the } \\
\text { collaborators. }\end{array}$ \\
\hline LIE2 & $\begin{array}{l}\text { Leaders are willing to offer opportunities for } \\
\text { employees to use their own criteria to do their } \\
\text { job. }\end{array}$ \\
\hline LIE3 & $\begin{array}{l}\text { Leaders are willing to empower their employees } \\
\text { so they can do their job. }\end{array}$ \\
\hline LIE4 & Leaders trust workers within the workplace. \\
\hline CUO1 & $\begin{array}{l}\text { The management style in the organization is } \\
\text { characterized by teamwork, consensus and } \\
\text { participation. }\end{array}$ \\
\hline CUO2 & $\begin{array}{l}\text { The organization is a very personal place, as an } \\
\text { extension of the family. People share a lot of } \\
\text { themselves with their peers. }\end{array}$ \\
\hline CUO3 & $\begin{array}{l}\text { The organization emphasizes human } \\
\text { development. There is trust, openness and } \\
\text { participation. }\end{array}$ \\
\hline CUO4 & $\begin{array}{l}\text { The management style is characterized by } \\
\text { promoting innovation, freedom, uniqueness and } \\
\text { individual risk. }\end{array}$ \\
\hline CUO5 & $\begin{array}{l}\text { The organization is a dynamic and business } \\
\text { space. Employees are willing to take risks. }\end{array}$ \\
\hline CUO6 & $\begin{array}{l}\text { The organization creates new projects, new } \\
\text { challenges, experiments with new things and } \\
\text { values the identification of new opportunities }\end{array}$ \\
\hline CUO7 & $\begin{array}{l}\text { The management style is characterized by } \\
\text { firmness, high demand and a sense of } \\
\text { achievement. }\end{array}$ \\
\hline CUO8 & $\begin{array}{l}\text { The organization is a work space very oriented } \\
\text { to obtain results. The biggest concern is reaching } \\
\text { the goals. The staff is very competitive. }\end{array}$ \\
\hline CUO9 & $\begin{array}{l}\text { The organization emphasizes competitive } \\
\text { actions and achievements: achieving difficult } \\
\text { goals in the market is very important. }\end{array}$ \\
\hline CUO10 & $\begin{array}{l}\text { The management style is characterized by } \\
\text { offering job security, is cautious and conformist, } \\
\text { as well as being stable in their relationships. }\end{array}$ \\
\hline CUO11 & $\begin{array}{l}\text { The organization is very stable and structured. } \\
\text { There are procedures that generally govern staff } \\
\text { activities. }\end{array}$ \\
\hline CUO12 & $\begin{array}{l}\text { The organization emphasizes stability and } \\
\text { performance. Efficiency and control of the } \\
\text { operation are very important. }\end{array}$ \\
\hline
\end{tabular}

Table 10 Instrument used during piloting

Source: (Liao, 2011), (Chen and Shui, 2015), (Ahearne et al, 2005; Arnold et al., 2000; Martin \& Bush, 2006), (Cameros \& Quinn, 1999)
ARREDONDO-SAFA, Judith, PEREZ-ROMERO, Luis Alfonso and CASTRO-VALENCIA, Alberto Merced. Study on knowledge management and open innovation. ECORFAN Journal-Republic of Peru. 2019 


\section{Acknowledgments}

A cordial thanks is extended to the Autonomous University of Guadalajara, the Center for Technological Innovation and Services for the Food Industry (CITSIA) and the Jalisco Agricultural Council for the support provided for the preparation of this pilot.

\section{Conclusions and recommendations}

During the pilot, it has been possible to confirm the existence of a consistent and feasible theoretical model to be measured through the proposed instrument. The above for the verification of the validity of criteria and construct through the reliability and normality tests mentioned above.

Subsequently, it was possible to verify through the confirmatory factor analysis the existence of three clearly defined factors: leadership, organizational culture and knowledge management. The above confirming the results obtained by authors such as (Naranjo - Valencia, 2012), (Stock, et al. 2010), (Suppiah, 2010), (Valmohammadi, 2010), (Yew Wong, 2005), among others. Likewise, two factors were obtained after the factorial analysis of the open innovation construct confirming what was mentioned by the authors (Chen and Shui, 2015), (Martínez-Conesa, 2017), (Popa, Soto - Acosta, 2017). Finally, it was possible to verify through the analysis of bivariate correlations, the existence of significant relationships between leadership and organizational culture with knowledge management and in turn, knowledge management and innovation among themselves..

Based on the results obtained, it is based on the assumption that knowledge becomes the most important asset of an organization and that managing knowledge is essential to convert tacit knowledge to explicit, retain individual knowledge, manage intellectual property and Promote a culture of innovation. This requires information storage mechanisms, the development of dynamic skills, technological resources, but, above all, human talent.

Knowledge management generates a virtuous spiral that is born from disordered data and is transformed into relevant and timely information. Information when analyzed and apprehended becomes knowledge.
In turn, this knowledge is the basis of innovation. This occurs through the organization's absorption capacity, the promotion of Research and Development and the potentialization of its know-how, which in turn translates into competitive advantages. In this way, the intellectual capital of the organization is strengthened, helping to achieve its strategic objectives, to strengthen its capacity for adaptation and resilience and to take the lead in establishing future market trends.

For future research it is recommended to incorporate new variables for the understanding of the Knowledge Management variable. These can be technological advances, human resources practices, effective communication, among others. Also, apply the instrument used in other socioeconomic contexts to know its results.

\section{References}

Ahearne, M., Mathieu, J., \& Rapp, A. (2005). To empower or not to empower your sales force? An empirical examination of the influence of leadership empowerment behavior on customer satisfaction and performance. The Journal of Applied Psychology, 90(5), 945-955.

Ahuja Sánchez, L., \& Pedroza, A. (2011). XV Congreso Internacional de Investigación en Ciencias Administrativas. Análisis del Sistema Nacional de Innovación en México, (págs. 114136). Veracruz.

Akhavan, P., \& et al. . (2014). Examining the relationships between organizational culture, knowledge management and environmental responsiveness capability. The Journal of information and knowledge management systems, Vo.l 44, No. 2, 228-248.

Alavi, M., \& Leidner,D. (2001). Knowledge Management and Knowledge Management Systems. MIS Quarterly Vol. 25. 107-136.

Albornoz, M. (2009). Indicadores de innovación: las dificultades de un concepto en evolución. Revista CTS, No. 13, Vol. 5, 9-25.

Baccarne, B., \& Logghe, S. (2016). Governing Quintuple Heliz Innovation: Urban Living Labs and Socio-Ecological Entrepreneurship. Technology Innovation Management Review, 22-30. 
Collins, C., \& Smith, K. (2006). Knowledge exchange and combination: the role of human resource practices in the performance of hightechnology firms. Academy of Management Journal, Vol. 49, No. 3, 544-560.

Chang, Y. \& Hughes, M. (2011). Internal and external antecedents of SME's innovation ambidexterity outcomes. Management Decision, 49. 1658-1676.

Chen, Y.-T. (2012). Sketch industry promotion framework for Smart Living Services by leveraging Living Lab Harmonization Cube. International Journal of Electronic Business Management, Vol. 10, No. 2, 149-162.

Chesbrough, H. (2017). The Future of Open Innovation. Research - Technology Management Jan- Feb, 35-38

Choo, C.W. (1996). The Knowing Organization: How Organizations Use Information to Construct Meaning, Create Knowledge and Make Decisions. International Journal of Information Management, Vol. 16, No. 5, 329340.

Delmonte, A. (2004). The Relationship Between Social Interaction and Knowledge management System Success. Journal of Knowledge management Practice.

Drucker, P. (2006). La Nueva Sociedad de Organizaciones. Gestión y Estrategia, 129-137.

Echeverría, J. (2008). El Manual de Oslo y la Innovación Social. ARBOR Ciencia, Pensamiento y Cultura CLXXXIV, 609-618.

Eriksson, M., Niitamo, V.-P., \& Kulkki, S. (2005). State of the art in utilizing Living Labs approach to user - centric ICT innovation - a European approach. Centre for Knowledge and Innovation Research, 1-13.

Essers, J. \& Schreinemakers, J. (1997). Nonaka's Subjectivist Conception of Knowledge in Corporate Knowledge Management. Knowl.Org 24 No. 1, 24-32.

García Robles, A., Hirvikoski, T., Schuurman, D., \& Stokes, L. (2015). Introducing ENOLL and its Living Lab Community. ENOLL. Brucelas, Bélgica: ENOLL.
Gassmann, O. \& Enkel. (2006) E. Towards a Theory of Open Innovation. In. R\&D Management Conference

Gil, A., \& Carrillo, F. (2013). La creación de conocimiento en las organizaciones a partir del aprendizaje. Intangible Capital, Vol. 9, núm 3, 730-753.

González Sánchez, R., \& García Muiña, F. (2011). Innovación abierta: un modelo preeliminar desde la gestión del conocimiento. Intangible Capital, Vol. 7, núm. 1, 82-115.

González Santoyo, F., \& Flores Romero, M. (2018). Sitación actual y perspectivas de la ciencia y tecnología en México. INCEPTUM, Vol. XIII, No. 24, 23-42.

Hair, J., Anderson R., Tatham R., Black W. (2007), Análisis Multivariante, 5a. ed. Prentice Hall Iberia, Madrid, 1999, 832 p.p.

Hung, S.-C. (2004). Explaning the process of innovation: The dynamic reconciliation of action and structure. Human relations, Vol. 57 No. 11, 1479-1497.

Hurmelinna-Laukkanen, P., \& Ritala, P. (2010). Protection for profiting from collaborative service innovation. Journal of Service Management Vol. 21, No. 1, 6-24.

INEGI (2018), Directorio Estadístico Nacional de Unidades Económicas, https://www.inegi.org.mx/app/mapa/denue/

Jaworski, B. \& Kohli, A. (1993). Market Orientation: Antecedents and Consequences. Journal of Marketing Vol. 57. 53-70.

Kovács, K. (2015). Evaluation and Practice of Interactive Value Production in Living Labs. Periodica Polytechnica Social and Management Sciences, 52-59.

Lazzarotti, V., Manzini, R., Pellegrini, L. (2011) Firm-specific factors and the openess degree: a survey of Italian firms. European Journal of Innovation Management Vol. 14. 412-434

Leminen, S. (2015). Q\&A What are living labs. Technology Innovation Management Review, Vol. 5, Issue 9, 29-35. 
Lovera Aguilar, M. (2009). La organización creadora de conocimiento: una perspectiva teórica. Omnia, Vol. 15, núm. 2., 178-193.

Martín-Rojas, R., García-Morales, V., García Sánchez, E. (2011). The influence on corporate entrepreneurship of technological variables. Industrial Management \& Data Systems, Vol. 111 No. 7. 984-1005.

Martínez Conesa, I., Soto Acosta, P., \& Carayannis, G. (2017). On the path towards open innovation: assessing the role of knowledge management capability and environmental dynamism in SME's. Journal of Knowledge Management, 553-570.

Mathison, L., \& Gándara, J. (2007). Innovación: factor clave para lograr ventajas competitivas . Negotium, Vol. 3. núm 7, 65-83.

Nonaka, I. (1994). A Dynamic Theory of Organizational Knowlegde Creation. Organization Sience, Vol. 5, 14-37

Ocak, S., Ali, M., Bertsch, A. (2015). Linkages among organizational culture, knowledge management and patient safety performance. Int. Management and Enterprice Development, Vo. 14, No. 1. 11-35

Organización para la Cooperación y el Desarrollo Económico (OCDE) y Eurostat. (2005). Manual de Oslo, Tercera Edición. Grupo Tragsa.

Ortíz Cantú, S., \& Pedroza Zapata, A. (2006). ¿Qué es la gestión de la innovación y la tecnología? Journal of Technology Management \& Innovation, 64-82.

Parmar, P. \& Mulla, Z. (2015). Impact of Empowering Leadership and Trust on Attitude towards Technology Adoption. NMIMS Management Review 24-44.

Popa, S., Soto - Acosta, P. , Martínez - Conesa, I. (2017). Antecedents, moderators and outcomes of innovation climate and open innovation. Technological Forecasting \& Social Change. 1-9.

Ren-Zong, K., Ming-Fong, L., Gwo-Guang, L. (2011). The impact of empowering leadership for KMS adoption. Management Decision Vo. 49. 1120-1140.
San Martín Albizuri, N., \& Rodríguez Castellanos, A. (2012). Un marco conceptual para los procesos de innovación abierta: integración, difusión y cooperación en el conocimiento. Telos, Vol. 14, No. 1, 83-101.

Schneckenberg, D. (2015). Open innovation and knowlede networking in a multinational corporation. Journal of Business Strategy, Vol. 26, No. 1, 14-24.

Shuurman, D., De Marez, L., \& Ballon, P. (2013). Open Innovation Processes in Living Lab Innovation Systems: Insights from the LeYLab. Technology Innovation Management Review, 28-36.

Soto - Acosta, P., Popa, S. \& Martínez, I. (2018). Information technology, knowledge management and environmental dynamism as drivers of innovation ambidexterity. Journal of Knowledge Management.

Stock, G., McFadden, K., Gowen, Ch. (2010). Organizational Culture, Knowledge management, and Patient Safty in U.S. Hospitals. The Quality Management Journal Vol. 17. 7-26.

Takeuchi, H. (2013). Knowledge-Based View of Strategy. Universia Business Review, 68-79.

Van Geenhuizen, M. (2018) A framework for the evaluation of living labs as boundary spanners in innovation. Environment and Planning C. Politics and Space. 1-19

Von Hippel, E. (2002). Open source projects as horizontal innovation networks. MIT Sloan School of Management, Working Paper 436602, 1-27.

Valencia Rodríguez, M. (2015). capacidades dinámicas, innovación de producto y aprendizaje organizacional en PYMES del sector cárnico. Ingeniería Industrial, Vol. XXXVI, No. 3, 297305.

Veliz, C. (2017). Análisis Multivariante: métodos estadísticos multivariantes para la investigación. CENGAGE Learning.

WIPO (2017). World Intellectual Property Indicators 2017. Geneva: World Intellectual Property Organization. 
Wang, X. \& Xu, M. (2018) Examining the linkage among open innovation, customer knowledge management and radical innovation. Baltic Journal of Management Vol. 13-368-389.

Wu, I.-L., \& Hu, Y.-P. (2018). Open innovation based knowledge management implementation: a mediating role of knowledge management design. Journal of Knowledge Management.

Yew Wong, K. \& Aspinwall, E. (2005). An empirical study of the important factors for knowledge - management adoption in the SME sector. Journal of Knowledge Management, Vol. 9, No. 3. 